\title{
THE RIGHT OF RECAPTION OF CHATTELS
}

R. R. Sruart and L. H. Lugh'

Of all the many forms of eelf-help, probably the most ill-defined and an definite is the right of recaption, which arises, in a general way, when a person who has somehow been dispossessed of his chattels seeks to retake them withulat recourse to law. In what siruations, and in whar manner he may du so. it is the purpose of this article to discover.

\section{HISTORI:}

The right of recaption, broadly defined, has existed for a very long rume. although the centuries have seen great changes in its application and sropx. For instance, in the early Anglo-Norman period, and even 25 late as the foutr teenth century, the right was only allowed when the owner was in fresh pursuit and the retaking accompanied with the most solemn legal and religious formt: be.' Non-compliance with these requirements led to forfeiture of the chartels. In the words of Professor Maitland:

Our common law, which in later days has allowed a wide sphere to recaptufe . seems "I"

have acarted in the twelfith and chirreenth eenturies with a stringent prohubition of iniormai cell-help ....

By the time of Coke, the right of recaption was recognized in English lan. although subject to real restrictions as to the amount of force permissible in retaking the chattels. The following quotation from Blackstone's Comment. aries illustrates this point:'

When any one hath deprived anothet of bis peoperty in goods of chaccels personal . . . the owner of the goods may lawfully claim end remke them whetever he may lind inem. w it hy not in a ciocous manner, or atcended with a breech of the peace.

By the middle of the nineteenth century the right had expanded considerably. The culmination of this expansion appeared in Blades v. Higgs," where it was held that the owner of goods wrongfully witheld may use reasonable forec in retaking them, whecher che posesession of the other party was rightful ur wrongful in its inception. At about the same time the Supreme Court of New Brunswick held that even were a breach of the peace to result from such a rt. capture, the retaker would not be civilly or criminally liable.

In our submission however, the right of recaption is once more being cir. cumscribed by the courts, and the modern tendency seems away from self-help. except where it is obvious that removal of the right would give rise in real hardship.

'R. R. Stuart and L. H. Leithe firt year bow.

1 Pollack and Maicland, History of Engliah Low (2ad ed., 1911), vol. 2, p. 168.

I6id., at p. 169.

- Blackatone' Commentaries (1902), 111. 34.

- Blades v. Hikes (1861), 10 CB. (N.S.) 713.

- In Graham v. Green (1862), 10 N.B.R. 330. 


\section{THE PROBLEM}

Before the right can be exercised at all, the chattels must be of a class subject to recapture. Animals detained domage feasant in a pound," unbranded animals ferce naturae." and goods distrainable either for rent or under hire. purchase agreement" fall outside this class. Another and obvious limitation is that ritle must still be in the owner. If title has passed, as to a third party bv means of a voidable contract, the former owner may not. retake the goods. Exrept where specifically stated below, the goods in all situations discussed will be regarded as generally subject to recaprure."

Any examination of the right of recaption must necessarily onncern itself with three main topics:

1. Recaption not invoiving torce or entry upon the land of another.

2. Recaption involving the use of force but not entry on another's land.

3. Recaption involving entry on the land of another."

These three sections will be discussed primarily on a basis of the fault involved in tise original taking. since that is the basis upon which most of the relevant decisions have been founded. There is, for example, a great difference between the right to recapture goods stolen and those taken only tortiously, or between the right to retake gonds lust accidentally and those lost through the fault of the owner.

\section{PEACEFLIL RECAPTION NOT INVOLI'ING ENTRY ON ANOTHER'S LAND}

It the "nacural right of recaption" exists at all it must surely exist where the owner of the reods, having been wrongfully dispossessed, subsequentlv retake the goods pesusully." As East put it in his Pleas of the Crown:':

\footnotetext{
"Animals dumage feasomt may nor be resaptured from a pound without payment for the damere done. The Domestic Animals Act (Munstipaluties), R.S.A.. 1942, c. 91. 8. 33, and the Domestic Anmmals Act (Unorganized Teerstorv). R.S.A., 1942. 692 , 41 Pound breach is : ise an offerce punishable on summarv conviction with a maximum fine of stov. Not all per ue nuturar are the subpect of a mere qualitied propertv. The Game Art. 1946 (Alea.) c. 4. 3. 4. provides that all branded animals whall remein the property of the brander wherever the snumak maY Ru in the provinere. On prinijple this would ween to

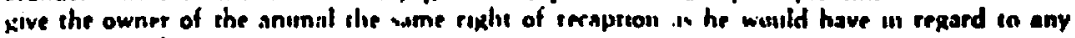
wethet personal propertr.

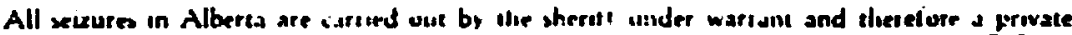
person. even though entrited to slue gouds insy not seize them The Sezzurn Aic. R S A. 1042, . 143

"When the owner's gouds have been commingled un surh a marines as to render them in. separable and indistingusshable, the wronged ownet bernmes a tenant-in-iommon if the commingleng was donr corricusly. and the cole uwner is it wiss dune criminally. If the comningling wax done creminally the owner lose the sume rughis ut exaption as be lias in

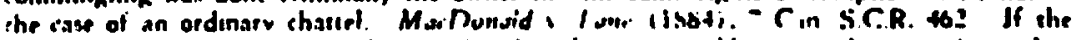

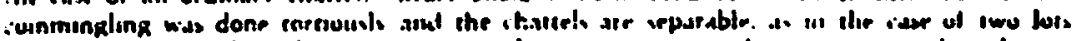

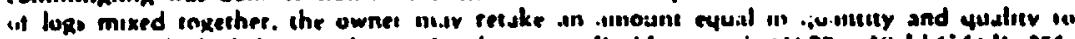

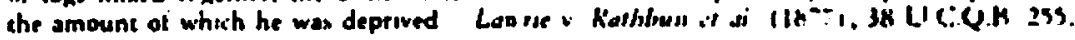

:- With spectul problems relateng to the use of torce in the situstion

This is keneraliy admuted. See. eq. Blackstone' Commentantes a14021, at p. 111. 4: Salmond on Torts 110th ed. 1045s. 141; Winfie:d on Turts loth ed.. 14i4t, t37.38: Polloxt on Tors (1):h ed.. 19511. 293: and Brankton. The Fursible Rexaption of Chatrels (1912). 28 1. QR. 26: f!.

II East; Ptres of the Crown. :
} 
A person whoce goods have been srolen has the right to recake them peacesbly

, unless, s:ni, che uking by the thief. something bas occurred to divene the ownst title.

Much later, in Rayson v. Graham, ${ }^{18}$ Richards C.J. said confidently:

The rule that the ownet of personal property might take is wherever he could tend it if 1 .

daj not remmit a breach of the peace or reespess on the close of another is well enteblished.

A similar expression of confidence is seen in McMullin v. Campbell." a Nova Scotia decision.

So long as a person has an immediate right to possession, which could be enforced judically," and retakes his goods peacefully, no-one has a righe to complain, for he has harmed nobody, and by acting speedily has averted a real danger of possible injustice. "For instance, it has been held that where a land. lord illegally takes inoney owing him from his tenant, the tenant has every righs to retake it peacefully." Similarly, the owner, if he uses no force, may retake the goods from an innocent third party who has not obtained a valid title," and even if title has passed, the owner will be guilty of no crime if he retakes them in this way, believing himself entitled to do so."

\section{RECAPTION INVOLVING THE USE OF FORCE}

The question as to when one may use force to retake one's chattels is by nr. means a settled point. The American Restatement of the Law of Torts lays down several necessary prerequisites to its use which may be summarized as follows:

1. The possession must be wrongful. It is impossible to quartel with this, since if the dispossessed party uses force in retaking goods held rightfully by another, he will be held liable for the battery, no matter how reasonable his mistake."

2. The owner must have been dispossessed, as well as having a right to pos. session. This of course, is implict in the word "recaption".

3. The right to possession must be immediate. This is eminentiy reasonable, since if there is no immediate right to possesvion, as where goods are legally held for security, the owner does not even have the right to retake them peaceabls If he "reverts to man's primeval instincts", he does so at his own risk."

\footnotetext{
i2 Rgron v. Grahem (1864), is U.C.C.P. 36, it p. 38.

14 MoMullin v. Complell (1920), S4 N.S.R. 164, at p. 165

23 Phillops v. Murror, [1929] 2 W.W.R. 314, approving Stlmand an Torts ( (10th ed., 1949). 19:3.

it The goods mul have been desereyed or caken to sone unknown plece. Thewe dangers are poinced out by Winfield and Pollock, loc. cir.

1: As in Austin v. Dowting (1870), L.R.SC.P. 534.

14 As in Bowon v. Yielding. M.T. 3 Vict., aperted in the Digent of Onterio Cuse Lav, 111, 6904.

Iv A pervon obking back his goods undor the impression that he has a right to do so cannot be convieted for chefe, altheugh be may be coovinand of an aveult perpertated in 10 doing. $R$ v. Boden (1844), 174 E.R. 863.

to Reateternent, Torts, as. 100-105.

as Supre, foomote 19.

22 Branston, op. cir. 262. Nykobn v. R., [1949] S.C.R. 392.
} 
4. The owner must first make a demand for the retum of the chattels, unless such demand be unreasonable under the circumstances. Although there is no direct authority in English or Canadian law for this proposition, it is submitted that the extremely reasonable view of the Restatement ought to prevail as it might serve to lessen some of the dangers inherent in a too teady resort to force.

5. The owner must act promptly, and cannot use force if he is not in fresh pursuit of has chattels. American cases such as State v. Dooley": support this statement, although it is doubtful if it correctly expresses the law in Canada.

These propositions cannot too readily be accepted as the law in Canada, unfortunately, since against their clarity stands a mass of apparently conflicting dicla, both English and Canadian.

Originally, unless the pursuit was fresh, one could not in recapturing the goods, use any force at all, and if it were used, all right to the goods was im. inediately forfeit." Even later cases like that of Shingleton v. Smith" contain statements to the effect that a servant may justify a battery in defence of his master, but not in defence of his master's goods. Blackstone expressed the view of the eighteenth century lawyers when he wrote: "it

As the public peace is a superior consideration to eny one man's private property. and ii individuals were once allowed to use privete force as a remedy to privace injuries. all social nuscree would cease. the strong would give lew to the weak, end every man would revert to s scate of narure: for these reseoss is is providad that the notural right of excopecon shall novee be exested where such erertion must occasion strife or bodily contention, or endanger the peace of soxiery. ... It for instance ony horse is takes sway... I cennok justify lreenking him [orcibly]. . exceps he be felonicusly seolen ...

The validity of this statement was soon thrown into doubt. In Goodhart v. Lux'e, Lord Eldon L.C. stated that "if the plaintiff has a tight to the goods, he mav lay his hands upon and recover them, if he can; indeed Buller J. used to sav, by any means short of felony":" In Rex v. Milion," where the defendant irfused to give up a search warrant to the officer who had shown him it, and a violent iracas ensued, it was held that a person can retake goods wrongfully caken from him, and of which he has the right to custody, using no more force than is necessary. However, the court added the provisio that if unnecessary force was used, the other party might retaliate. Finally, in Blades v. Higgs,"; where the oietendant's servants had forcibly retaken rabbits from the plaintiff, a pnacher, it was held that reasonable force might always be used against anyone wrongfully detaining one's goods, and perhaps even against an innocent third party. But as is pointed out by Pollock," "if the test is that A must use no

$\because$ Situte v. Dooler (1894). 26 S.W. 558. Held within a resconsble distance and therefore within s reewnebte tume were 100 rods in State v. Elliot (1841), I1 NH. 540, and several miles in Hoineden v. Hubberd (1846), 46 Am. Dex. 167. See renerelly: Rentalement, lac. eit.; and Prosser on Toros (20d ed., 1955). ton

-1 Pollock, op. cat., 293.

25 Shingleton v. Smish (1699), 2 Lut. 1482; 123 E.R. 816.

:0 Blackstone. op. cit.. 4.

21 Goodhot v. Lowe (1820), 2 Jac. W W 349; 37 E.R. 661.

$\therefore$ R. v. Milion (18271. M.eM. 107; 173 E.R. 1097, a p. 1098.

$\Rightarrow$ Bledes $\nabla$. Higgs (1861), supra, foomon 4.

to Pollock, op. cit. 293. 
more force than is necessary, and as this necessarily varies with the facts of each case, self-help is likely to be just as dangerous a remedy here as elsewhere".

Yet the courts, at least in Canada, seem to have retreated from this nineteenth rentury atrirude to the problem. In Phillips v. Murray,: a Saskatchewan decision, the court approved a dictum of Sir John Salmond's to the effect that recaption could not be tolerated unless the person forcibly recapturing the goods could haye obtained specific restitution of the goods in judicial proceedings. Significantly, Haultain C.J.S. went on to say:

It to a racher scarting docerine, and not at all conducive to the Krag's Peace, to hold that. in ordet te recoler property, however unjusutiably recained. the owner may unjure the wrongdoer as deiendant injured the plaintiff (severely beatune ham).

In 1951 the Supreme Court of New Brunswick in Devoe v. Long, ${ }^{3:}$ held emphatically that the use of force was never justified unless the adverse possesion was wrongful in its inception, and distinguished Blades v. Higgs". and the earlier New Brunswick decision of Graham v. Green" on the grounds that in hoth cases, the uriginal pussession was wrongful in the inception. Significant. ly also, the Canadian Criminal Code" only extends justification to the retaker if he "does not strike or cause bodily harm to the trespassct". Since the Code also states that the holder of goods under 2 reasonable claim of right may defend his possession as if he were the true owner," it would be strange if the law were even impliedly to authorize two parties to attack each other simultaneously. Of course it is probable that if an assault is necessary in the first place, it is because the wrongful taker is about to resist, and if he does so, he is deemed to commit an unprovoked assault. Nevertheless, forcible recaprion while probably authorized in thus country if retaking was wrongful in its inception. is at best an uncertain and dangerous remedy, to be exercised only with extreme caution, as where the goods are in danger of being lost or carried awav.

\section{RECAPTION INVOLVING ENTRY ON THE LAND OF ANOTHER}

We now turn to the third sphere of recaption, that is. recaption of chatteis from the land of another. It is in this sphere that most of the uncertainty in the law exists.

We shall discuss the right of recaption in this situation on a basis of fault and in the following order: first, the right when the occupier is at fault: second, the right when the owner of the chartel is at fault or the possession of the occupier was rightful in its inception; third, the right when the chattel caine on the land through the fault of a third party: and fourth when the chattel came on the land through one one's fault.

1. If the oceupier himself places the goods of another on his close:

the gives so the owner of them an umplied license wo enter for che purpone of recoptron :=

J1 [1929] 2 W.W.R. 314, at p. 316.

22 [1931] I D.L.R. 203.

is Supra, footnote 4.

3. Supre. foomore 5 .

2s $1953.54(\mathrm{Cmn}$ ) e. $31,8.38(1)$.

ac lbid. 2. 39 .

35 Pesich v. Colerick (1838), 3 M. \& W. 483: 150 E.R. 1235 at p. 1236. 
This statement is far too wide however, for the courts have hedged this license with restrictions, especially in regard to the use of force. For instance, if the caking was merely cortious, only reasonable force may be used and a breach of the peace is not permissible." If the taking was criminal however, and the occupier resists the retaking, the owner of the chartels may use suificient force to defend himself." It is submitted that the retaker may not use force to retake his chattels if the occupier is acting under a claim of right, whether the goods were stolen or only taken torriously.

2. When the occupier's possession was rightful in its inception, no force may be used to retake the chattel. This point, which has been the subject of contention ever since Blades v. Higgs." has recently been decided by the Supreme Court of New Brunswick in Deroe v. Long." The facts in that case were that the defendant had been in trouble with the Ineome Tax Department and had receiv. ed a letter from them. The defendant suspected that the plaintiff, who had worked for him, had reported him. and took the letter over to the plaintiff's home co show it to the plaintiff. An argument ensued and the plaintiff ejected the defendant who forgot to take the letter with him. The defendant later came back for the letter with his son, and upon the plaintiff's refusing to give the letter up, the defendant broke into the plaintiff's home and violently assaulted him. In his judgment, Harrison J. said:"

$\therefore$ the ploinciff's possession was osiginally lowtul but has been terminated by a request lism the defendant who is entitled to the possession of the charrel. In such cases the defend. ant may make an entry on the planniff's close to retake, bue only if such entry can be mede pemeably and not hy commiting a breach of the peace.

Thus :s will be seen that if the chattel came un the land through the tault of the owner of the chattel. he may not make entry upon the land of another to re. take it. This rule is the same whether the goods came on the land through inrent or through the owner's negligence.'

3. When the presence of the chatrel on the land is due to the act of a third party, the right of recaption depends upon the manner in which the chattel was originallv taken. and whether the oceupier was or was not aware of the presence of the thatrel on the land. and whether or not the occupier cunsented to the presence of the chatiel on the land.

- Supra, footnoote 32.

Suprd. foomote 33. s: 3t. 5-

1. Supra. foctnote 29.

- Supra. foocnote i:

$\because$ ibid., st p. 22:

is The Case of in. Fhurns Y.B. 6 Ed. ii., Pi. 18: Ansthany. Hower (1832), 8 Bung. 186, 131 E.R $3: 2$ 
If the chattel was taken criminally, ${ }^{\prime \prime}$ and the oceupier permitred its deposi: on his land, the owner of the chattel may enter the occupier's close to retake it." It is immaterial whether the occupier knew that the raking of the chattel was criminal. for if he assenes to its presence on the land, he:

. . . though not cogient of the felony, inuly incurs the riak of the thing ourning out to be stolen."

Presumably reasonable force may be used to retake the chartel excepe where the occupier of the chattel acts under a claim of right. There should at all events. be prior demand to enter before force is resorted to. If the oceupier was not cognizant of the presence of the chattel on his land, then the situation should be dealt with as if the chattels came on the land through the tort of a third party

When the chattel came on the land through the tort of a chird party, the siriation is rather different. There are three possible approaches to the prob lem. The first, for which there is no authority, is thas the owner of the chattel may enter on the land and retake it withour incurring any liability. The second approach treass any such entry for the purpose of recaption as a trespass. The third approach, and the one favoured by many Annerican jurisdicrions. is that the ownet has a license to enter for the purpose of recaption, but will be liable for any damage incidental thereto.

The view which ereats entry on the land as a trespass was the first to be ac cepted. In 1519, the court in Higgins v. Andrewes said: ':

Bur if JS. cake my bore and pue him in the land of J.D. it is not lawfui for ton to ente: on the land and onte him beceuse it is no felony.

In the later case of Patrick v. Colerick." the court was equally definite. Tinda! C.J. said:

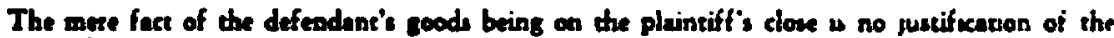
entry if it eannot be shown how they cane there.

This rigid position is also supported by Blackstone who writes: ".

... if for inseance ay borse is cuken awny . . . I cannot juscify bresking open - private iccible or entring upon the grounds of a third person to take him except he be feionsously stolen.

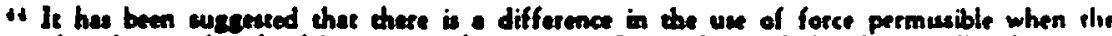
cherrel wes caten by felony or miadenesnour. . It is subsirted that historically. there wit no difference. All offences egeizat the goods of men were felonies in Hele's nime. Haie. Pleas of the Crown, p. 26. Before 1833 most offences deding with property were felonies and by the time that man bad bon made miademennours oy statute, criminal onking hed been equated with tortious enking in regard to use of force. Blades v. Higs, 142 E.R. 634. Winfield draw a diecinction on the sround that crespass was a mis-

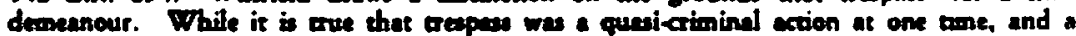
fine wes unpoed by the crown, the fine was not inpowed for the rrespas to chetrels or

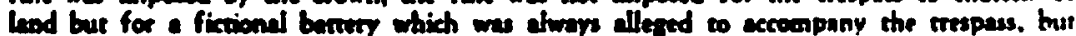
was never proved. Maidend, The Forme of Action af Conmon Law, al F. 67 The

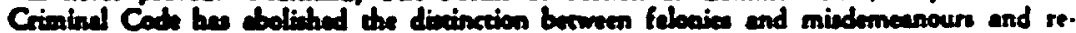

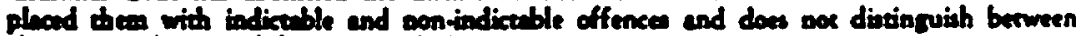

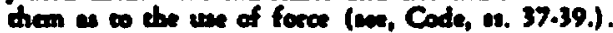

* Chapenen v. Tumblethorp, Cro. Eliz. 330, 78 ER. 579.

to Cunninghem v. Yromm, 7 N.S.W., 149; Bahlen, Canes on Torts, 104.

t7 Hizgins v. Andrewes, (1619), 2 Rolle, 81 ER. 656.

ty Supre, foomose 36, at p. 1237.

is Blectereone's Commentarios (1902), 117.5. 
The third spproach, which we call the theory of Qualified License, is more modern in origin and deriven its greatent support in the Unitod Stanen" The doctrine was firse set forth in decisive fashion in Chambers v. Bedell" a century ago. The most lucid esposition of this appronch is in the Reatatement of Torts which wys in part: ${ }^{32}$

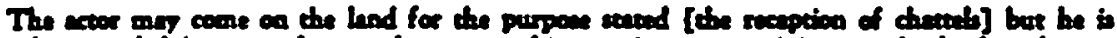

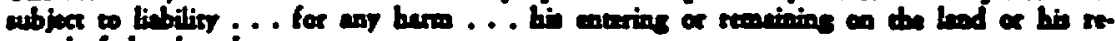

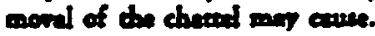

The doctrine of Qualified License has also found some support in English and Canadian courts. In the case of Anthony v. Hamey, Tindal C.J. in a dictum said: ${ }^{2 s}$

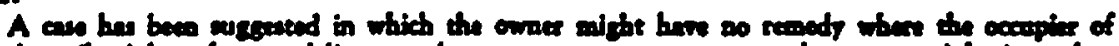

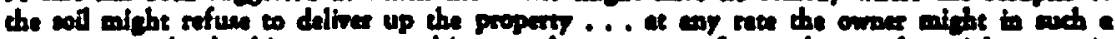

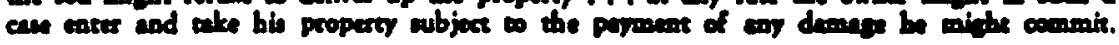

In the receat ease of Southport v. Esso, ${ }^{50}$ Devlin J. was prepared to hold that in cases of neceasity, entry must be allowed, but that the licensee must pay for any damage he might do while on the land. It may be argued by analogy that Devlin J.'s dictum ought also to apply to cases where the presence of the chattel on the land is due to the torcious act of a third party, for in such a case, as in necessity, neither the owner nor the cocupier is in any way at faule.

In Canada there are more dicta in favour of a qualified license that there are in England. In 1836 the Supreme Court of New Brunowiek were faced with the problem in Read v. Smith." In that case, timber came on the plainiffs. land through a sudden rise in the water level which set the defendanus booms adrift. The defendant then entered the plainiff's close to retake the logs. The court was not satisfied that the defendant had used sufficient care to pre. vent the logs from floating fret, but Chipman C.J. said, that had the defendanes oot been at fault: ${ }^{\text {s6 }}$

.. . there abould in ruch a case have bem a previous request to enter and ther must at all

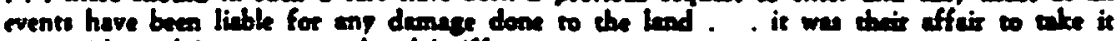
awey wichous doing wroas to the plaintiff.

This decision, strongly indicative of an approach to the qualified lioense theory was followed in Hamilton v. Calder" which decided that the owner of a

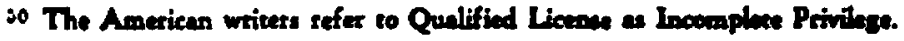

st Chombers v. Beddl (1841), 2 Wate a S. 225 (Peanowinia). -

is Restatement, Tors, \&. $198(2)$.

s8 A whowy v. Hency (1832), 8 Bing. 187, at 192; 131 ER. 372, at 374.

on Souhport Corp. v. Esso Potrolewm Ca. Led. at d. [1953] 2 All B.R. 1204, at 1206.

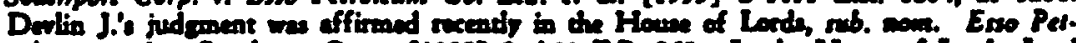

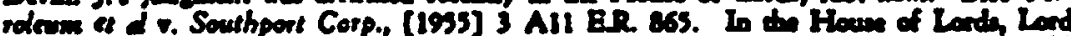
Morton, at p. 870, and Lord Redelife, at p. 872, were of the opinios that onewit would

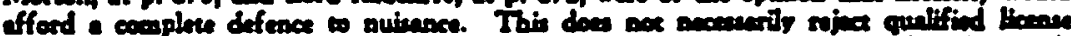

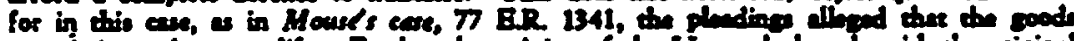

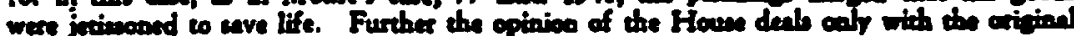

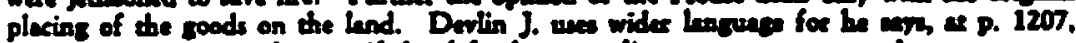

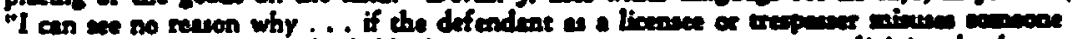

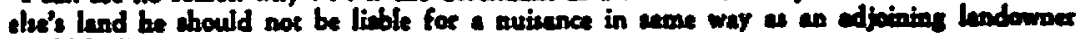
would be."

16 Rnd 7. Smith (1836), 2 N.BR, 288.

of Ibil., at p. 293.

or Hewillen v. Cdder, 23 N.BR. 373. 
chattel which is in the had of another through no fault of his own, has a right if refused permission to enter, to $g \circ$ in and recover hin goods. These cases would seen to indicate that in the Maritime Provinces at any rate, there is a trend towards a theory of qualified license.

Of the rext-writers however, the only ones who favour this theory are the Americans, particularly Professor Bohlen and Dean Prosser. Their view is that: ${ }^{\text {in }}$

.. . in such cess, the peivilege resubles thes of necenity, and since the plainciff is not a

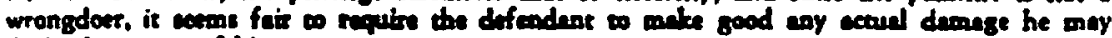
do in the coure of his entry. . . .

There is a solid foundation for this approach, which can easily be applied if the courts see fit and it affords in addition, the most equitable approach possible under the circumstances. The occupiet is in no way harmed because any damage done to his land will be paid for by the owner of the chattels, while the owner's losses will be minimized by avoiding a costly suit for the recovery of the chattels. Delay in reposeseaing the chatteds may wreak actual hardship on the owner while the occupier must mender the chattels eooner or later. Thus the owners interest far outweighs that of the occupiez and it should be so recognized.

It is submitted however, that demand to enter must first be made, and if permission to enter be refued, then the owner should not be allowed to provoke a breach of the peace." The owner may not if refused permission to enter, make a clandestine entry to recapture his goods In the case of $W$ entzell $v$. Vienot \& Hall, ${ }^{\text {, }}$ whese a wife sold her cow to the defendant Vienot, the hus. band refured to give the cow up and locked it in a stable. The defendant returned at wen p.m. with a polioe officer, Hall, broke into the plaintiff's stable and took the cow. The court held the defendants liable for treapass and strongly disapproved of the clandestine entry, anying that such a course was more fitting for a criminal than a police officer. Thus the gualified license would exist only when the occupier gave permission to enter or did not resist entry with force.

4. We shall now deal with two situations where the presence of the chattels on the land was due to no faule on anyone's part, that is, where the chattels came on the land through sccident of necescity.

When the chartels came on the lend by eccident, the owner of them may enter for the purpose of recaption, but he must show that they came there through no fault of his own." wrongful in its inception, no force may be used against him.

When the chattels were put on the occupier's dose through necessity, the ownet's righes are not clearly defined. It is settled that one may put his chattels

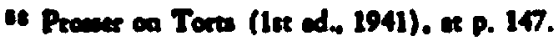

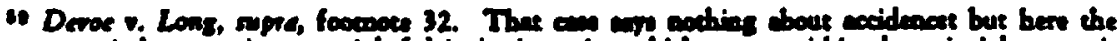

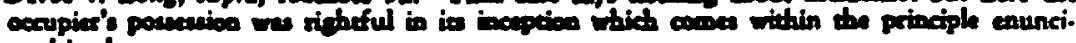
ated in thes case.

c Wentell v. Vienot a HAl, [1940] 1 DLR 536, 14 MPR 323.

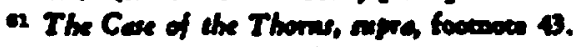

- Devor v. Lons, mpre, foumese 32.
} 
on the land of another if the chattels appeared to be in real and imminent danger, if it was the only way the chattel could be eaved, and if the owner acted reasanably. It has been doubted however if the owner has any right of recaption at all:"x The only authority on the subject is the previously noted dictum by Devlin J. in Southport v. Esso," which would give the owner a qualified license to enter and remove his chattels.

\section{CONCLUSION}

At least one writer," earefully surveying the history of recaption and the groweh of its application from functional non-existence in early times to a wide and recognized sight in the mid-nineteenth century, has concluded that the sphere of the right of recaption is steadily broadening. Yet at least as far as Canadian law is concerned, the passage of time has proved him wrong. There is a significant difference between the language of $R v$. Milton, ${ }^{\text {an }}$ for instance, and that contained in Phillips v. Murray." Once again, the right seems to be nartowing in scope.

However, at the present time, the right may probably be exercised in Canada in the following situations.

1. If the goods were stolen, the owner may retake them from the occupier or the thief without demand, using reasonable force if necescary, and an enter on the ground of the thief, or of one whose lands the goods have been placed, with his (the occupier's) privity or conseat, even perhaps to the extent of creating a breach of the peace."

2. If the goods were taken tortiously and the owner has an immediate right to possession, he can retake them from the wrongdoer, forcibly if the adverse possession was wrongful in its inception (although not perhaps, before a demand that they be surrendered), and otherwise only peacefully. He may come on to the wrongdoer's land to retake them, after a demand, on the same basis, but may in neither case create a breach of the peace."

3. If the goods have come into the possession of or on to the land of another by accident, and are of a class generally subject to recapture as defined eartier, the owner may retake them peacefully only, may not enter on the occupier's land before a demand is made, and even then may be liable for any harm incidental to the carrying out of this license."

us Salmond on Toru (10ch ed., 1945), p. 191. of. Presues on Tors (14 ed. ,1941) 147.

or Southport v. Esre. supras footrote S4.

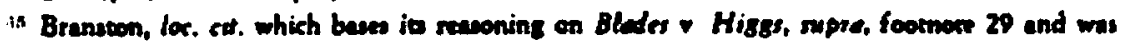
written over 40 years ago.

in Supra, foetnose 28.

it Supra, foornoces 15 and 31.

wh Band on Cunninghem v. Yromen (1868), 7 N.S.W. 149; Anshony v. Hency, 131 E.R. 372; Reed v. Smish, 2 N.B.R. 284; Henilion v. Cdder, 23 N.B.R. 373 and the clavie exponicores on the cubject tike Bleckerone who nogarded the search for a felon and the goods in the public rather thes pervece incerest.

wo Based on Deror v. Long, mora. foomote 32; and the perrusaive recthority of the Rerrete. ment, supre, footmote 20.

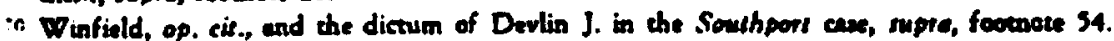


4. If the goods have come into the possession or on to the land of another through necessity, and are generally subject to recapture, the owner may not retake them before demand, and at moet will be allowed to enter the land to remove his goods only on the condition that he pay for any incidental damage."

5. If the goods have been stolen, are in the possession of an innocent third party, without his consent, and are generally subject to recapture, no force may be used or enery made, at least before demand, and a breach of the peace will nor be tolerated. The license so enter on the land may once again be a qualified one :-

6. If the goods have been taken tortiously, are in the possession of an innocent third party, and are generally subject to recapture, it is unlikely that the use of any force will be tolerated, especially if the adverse possession of the original miscreant was not wrongful in its inception. Entry on the posesesor's land will not be permitted before demand, and then only peacefully, pertaps once more in the form of a qualified license."

il A netromy v. Hency, 131 E.R. 372; Read v. Smith, 2 N.B.R. 288; and Hemilton v. Colder. 23 N.BR. 373.

:2 Conclusion 6 is besed on the mene authority a conclunion 5 with the addition of Drroe s Long. mepre footnote 32, and in the liethe of the Code.

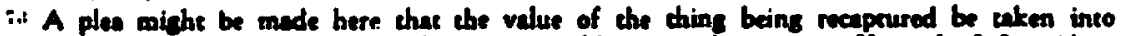

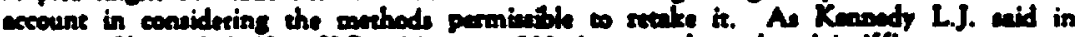
Cope v. Shap, [1912] 1 K.B. 496, at p. 500 (1 ceen where tho pleineiff' property wes

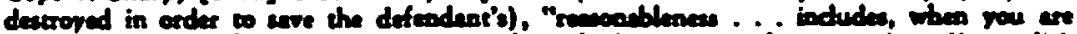

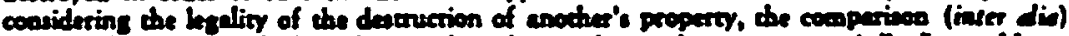

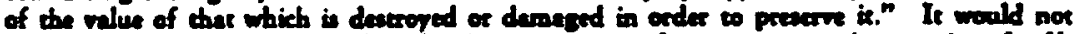

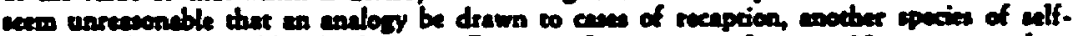

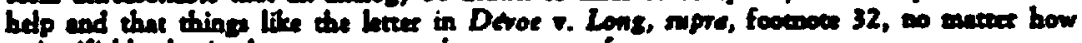

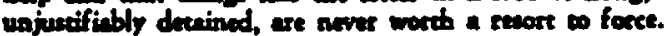

